\title{
STUDIES ON INDUSTRIALLY IMPORTANT ALKALINE PROTEASE PRODUCTION FROM LOCALLY ISOLATED SUPERIOR MICROBIAL STRAIN FROM SOIL MICROORGANISMS
}

\author{
SWAPNA VADLAMANI*, SREENIVASA RAO PARCHA \\ Department of Biotechnology, National Institute of Technology, Warangal, India \\ ${ }^{*}$ Corresponding Author- Email: swapnavad2003@gmail.com
}

Received: August 31, 2011; Accepted: September 17, 2011

\begin{abstract}
In the present study, 50 microbial strains were isolated from the soil samples from different regions of Andhra Pradesh. Among the isolates hyper producing strain namely, Bacillus Clausii was selected for alkaline protease production. The protease production efficiency of the organisms was measured with different environmental and nutritional parameters. The optimum fermentation conditions of production were temperature $40^{\circ} \mathrm{C}, \mathrm{pH} 8$ and time $32 \mathrm{H}$. Fructose, peptone and Copper sulphate as good nutritional sources for producing higher yields of the enzyme.
\end{abstract}

Keywords- Alkaline protease, Screening, Bacillus sp.

\section{Introduction}

Proteases are proteolytic enzymes that catalyze the breakdown of proteins by hydrolysis of peptide bonds. Proteolytic enzymes are ubiquitous in occurrence, being found in all living organisms, and are essential for cell growth and differentiation. Proteases represent one of the three largest groups of industrially important enzymes [4]. Bacteria are the most dominant group of alkaline protease Bacillus being the most relatively prominent and serve as an ideal source of these enzymes biotechnological importance $[6,14]$ because of their rapid growth and limited space required for their cultivation [1].

Among different types Acidic, neutral and alkaline proteases, alkaline protease plays very important role as most commonly used industrial enzyme in view of their activity and stability at alkaline $\mathrm{pH}$. They are used in detergent formulations, food, pharmaceuticals, and leather, in film industry, medical use and by waste processing companies [2, [5-6], [8-9], 12, 15]. Multiple application of these enzymes stimulated interest to discover them with novel properties and considerable advancement of basic research into these enzymes.

Proteases can be produced from wide diverse sources such as plants, animals and microorganisms. Protease can be produced by all microorganisms that produce a substantial amount of extracellular protease have been exploited commercially. Microbial proteases play a crucial role in numerous pathogenic processes mainly responsible for degradation of elastin, collagen, proteoglycons and also proteins that function in vivo host defence. Identification and characterization of microbial protease are prerequisite for understanding their role in pathogenesis.

\section{MATERIALS AND METHODS}

Isolation and Enzyme Production

Soil samples from different regions of Andrapradesh were collected.1gm of soil sample was taken in $250 \mathrm{ml}$ conical flask containing $100 \mathrm{ml}$ of sterilized water and contents were mixed well in an orbital shaker to get homogeneous suspension. The suspension is serially diluted $10^{7}$ times and using streak plate technique the diluted samples are transferred to petri-dishes containing sterile skim milk agar medium. After inoculation the plates were incubated at $37^{\circ} \mathrm{C}$ for 48 hours.

After incubation bacterial colonies appearing over skim milk agar medium were identified based on colony characteristics and their identities were confirmed through Gram staining methods and by a series of biochemical tests as prescribed by Bergley manual. For enzyme production, strain was cultured in $250 \mathrm{ml}$ of Erlenmeyer flask containing $100 \mathrm{ml}$ culture medium, which consists of $10.0 \mathrm{~g}$ of glucose, 5.0 peptone $\mathrm{g}, 5.0 \mathrm{~g}$ yeast extract, $5.0 \mathrm{~g}$ $\mathrm{K} 2 \mathrm{HPO} 4,0.1 \mathrm{~g} \mathrm{MgSO} 4.7 \mathrm{H} 2 \mathrm{O}$. The inoculated medium was placed in a thermostatic orbital shaker for $48 \mathrm{hrs}$ at $37^{\circ} \mathrm{C}$ and $120 \mathrm{rpm}$. The culture was centrifuged at 10,000 rpm for 10 min to obtain crude enzyme. 


\section{Protease assay}

Alkaline protease activity was determined with a modification of the method [6].1ml of suitable diluted enzyme solution was added to $5 \mathrm{ml} 0.5 \%$ (w/v) casein solution (dissolved in $50 \mathrm{mM}$ Tris-HCL buffer with $\mathrm{pH}$ of 8 ) and incubated at $55^{\circ} \mathrm{C}$ for $5 \mathrm{~min}$. The reaction was terminated with $5 \mathrm{ml}$ of $10 \%$ (w/v) trichloroacetic acid and the mixture filtrated through a filter paper. The filtrate absorbance was determined using Lowry method and extrapolated against a tyrosine standard curve. One unit of alkaline protease activity is defined as the amount of enzyme required to liberate $1 \mathrm{mg}$ of tyrosine per minute under the experimental conditions.

\section{Optimization of production parameters for higher enzyme yield \\ Effect of Nutritional parameters}

Nutritional parameters include nitrogen source, carbon source and metal ions. Firstly the respective nitrogen sources soya, malt extract, peptone, yeast extract, ammonium sulphate, ammonium chloride were added as a sole source of nitrogen $(0.5 \%, \mathrm{w} / \mathrm{v})$. The different carbon sources sodium acetate, sodium citrate, glucose, maltose, sucrose, starch and fructose were added as a sole source of carbon (1\%, w/v). Different metal ions (Fe, Cu, Zn, Ag, Li and $\mathrm{ca}$ ) were added as metal ion source $(0.1 \% \mathrm{w} / \mathrm{v})$. The enzyme activity was monitored for all different nutritional parameters after $24 \mathrm{~h}$ growth at $37 \mathrm{C}$.

\section{Effect of Environmental parameters}

Environmental parameters include $\mathrm{pH}$ (7-10), temperature (37-45) and time $(0-72 \mathrm{H})$. The enzyme activity was monitored for all the above parameters in the respective ranges.

\section{Results and Discussion}

The enzyme production was observed between temperature $\left(37-45^{\circ} \mathrm{C}\right)$ and $\mathrm{pH} 7.0-10.0$ "Fig. $(3 \mathrm{a}, \mathrm{b})$ ". The highest enzyme activity was observed at $40^{\circ} \mathrm{C}$ and also comparatively high activity was also observed at $37^{\circ} \mathrm{C}$, decrease in enzyme activity is observed with increase in temperature above $40^{\circ} \mathrm{C}$. The highest enzyme activity was obtained at $\mathrm{pH} 9$ and comparatively higher enzyme activity is also observed at 8. However, further increase in $\mathrm{pH}$ was not favourable on enzyme production. It was reported that proteases secreted by Bacillus sp. presented activity at a wide range of $\mathrm{pH}(7.0$ to 11.0$)$ and temperature $\left(30^{\circ} \mathrm{C}\right.$ to $\left.60^{\circ} \mathrm{C}\right)$ [6-8]. The growth curve of the bacillus species "Fig. $(3 \mathrm{c})$ " was observed and activity at every $4 \mathrm{~h}$ intervals and activity along with growth increase in the exponential phase and maximum activity is observed in the stationary phase at $32 \mathrm{~h}$, The production of an extra cellular proteolytic enzyme during the stationary phase of growth is a characteristic of many bacterial species $[11,13]$ and the activity decreased along with growth in the decline phase.

\section{Isolation of bacteria}

Bacteria producing alkaline protease were isolated from soil by serial dilution techniques. Superior microbial strain having high productivity is selected from zone of hydrolysis assay. The isolated bacteria having maximum zone of hydrolysis "Fig. (1)" were identified through a series of biochemical tests (Table 1) as Bacillus sp for further confirmation the sample was sent to IMTECH Chandigarh and the biochemical characterization results were shown in Table 1.

\section{Effect of Nutritional parameters}

The effect of different nutritional parameter on enzyme production was represented graphically "Fig. (2 a, b, c)" below. Among different carbon sources tested fructose has significant positive impact on both growth as well as higher enzyme yields. Maltose and glucose also had positive impact comparatively where as starch, sucrose had very less impact and sodium citrate, sodium acetate almost had no significant impact on both growth as well as enzyme yield. Organic carbon source have been found to be better carbon source for growth and protease yield $[3,10]$. Among different nitrogen sources organic nitrogen sources showed significantly increased activity where as inorganic nitrogen sources showed very low almost negligible activity. The negative effect of inorganic nitrogen sources on protease production by Bacillus sp. has been observed in earlier investigations [15]. The repression of protease biosynthesis may be ascribed to the release of ammonia from these inorganic nitrogen sources. Among the various metal ions tested $\mathrm{Ag}, \mathrm{Cu}$, $\mathrm{Li}$ and $\mathrm{Zn}$ showed high enzyme activity and maximum activity was observed using $\mathrm{Cu}$ and $\mathrm{Ag}$ ions. Where as the activity was comparatively low for $\mathrm{Ca}$ and $\mathrm{Fe}$ ions.

\section{Effect of Environmental parameters Conclusion}

Bacillus clausii can be used profitably for large scale production of alkaline protease to meet the present day demand of the industrial sector. Fructose, peptone and $\mathrm{Cu}$ best nutritional parameters for an enhanced enzyme production with optimum range of $\mathrm{pH}$ (8-9) and temperature $\left(37-40^{\circ} \mathrm{C}\right)$. Hence, further analysis on these medium components with reference to their specific role in the induced production of the enzyme is a very much necessary for motivation of further studies.

\section{References}

[1] Arulmani M., Aparanjini K., Vasanthi K., Arumugam P., Arivuchelvi M.and Kalaichelvan P.T. (2007) World J. Microbiol. Biotechnol., 23, 475-481

[2] Banerjee C.U. Sani R.K., Azmi W., and Soni R.(1999) Proc. Biochem., 35, 213-219.

[3] Berhor R.W. and Novelli C.D.(1963) Arch. Biochem. Biophys., 103, 94-97. 
[4] Chu W.H (2007) Journal of Industrial Microbiology Biotechnology, 34, 241-245.

[5] Dias D.R., VilelaDM., Silvestre M.P.C., Schwan R.F. (2008) World Journal of Microbiology and Biotechnology, 24, 2027-2034.

[6] Gupta R., Beg Q.K., andLorenz P. (2002) Applied Microbiology and Biotechnology, 59, 15-32.

[7] Horikoshi K. (1999) Microbiology and Molecular Biology Reviews ,63, 735-750.

[8] Joo H.S., Kumar C.G., Park G.C., Kim K.T., Paik S.R. and Chang C.S. (2002) Process Biochemistry, 38, 155-159.

[9] Joo H.S., Kumar C.G., Park G.C., Paik S.R. and Chang C.S. (2003) Journal of Applied Microbiology, P5, 267-272.
[10] Kitada M. and Horikoshi R. (1976)Can. J.Microbiol., 54, 383-385.

[11] Mandelstam J. (1960) Bacteriol. Rev., 24, 289 293.

[12] Naja M.F. and Deobagkar D. (2005)Electron. J. Biotechnol., 8, 198-207.

[13] Pollock M.R. (1962)The Bacteria Dunsalus, Acad. Press, New York(1962).

[14] Ramakrishna D.P.N., Gopi N.R. and Rajagopal S.V. (2010) Intl. J. Biotechnol. Biochem., 6(4), 493-504.

[15] Saeki K., Ozaki K., Kobayashi T. and Ito S. (2007) Journal of Biosciences and Bioengineering, 6, 501-508.

Table 1-Biochemical Characteristic of isolated bacteria. + positive result, - Negative result:

\begin{tabular}{|c|l|c|}
\hline S.No & \multicolumn{1}{|c|}{ Test } & Result \\
\hline 1 & Gramstain & + \\
\hline 2 & Growth on MacConkey Agar & + \\
\hline 3 & Indole Test & - \\
\hline 4 & Methyl Red Test & - \\
\hline 5 & VogesProskauer Test & + \\
\hline 6 & Citrate Utilization & + \\
\hline 7 & Casein Hydrolysis & - \\
\hline 8 & Starch Hydrolysis & - \\
\hline 9 & Urea Hydrolysis & + \\
\hline 10 & Cytochrome Oxidase & - \\
\hline 11 & Catalase Test & + \\
\hline 12 & Nitrate Reduction & \\
\hline 13 & H2S Production & \\
\hline
\end{tabular}

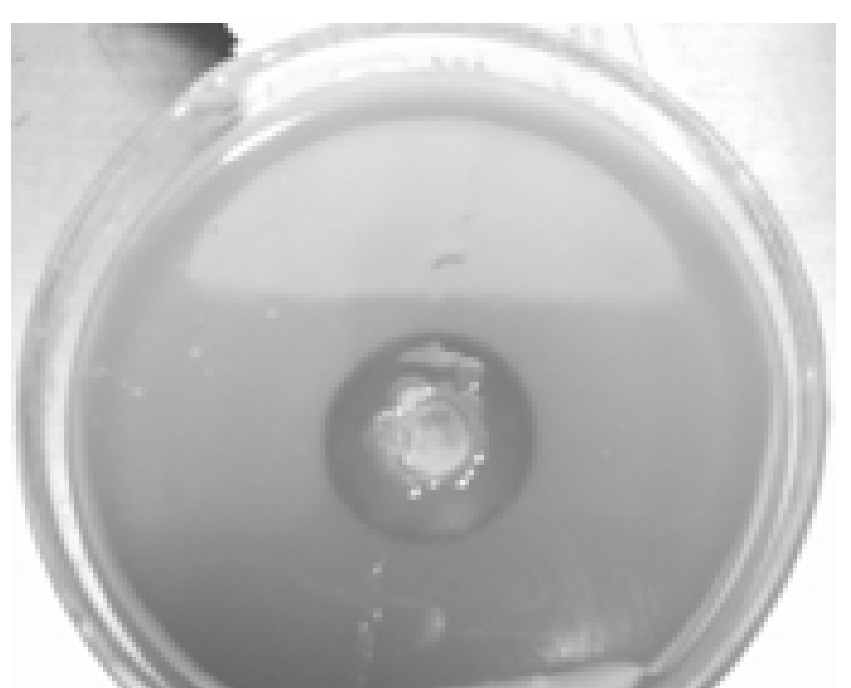

Fig 1. Zone of hydrolysisactivity assay for superior alkaline producing microbial strain. 
a) Carbon source

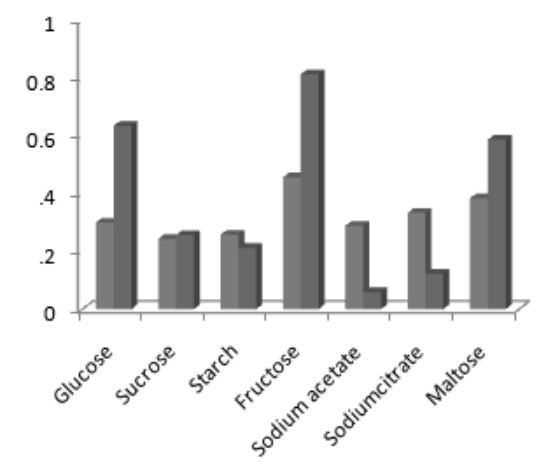

b)Nitrogensource

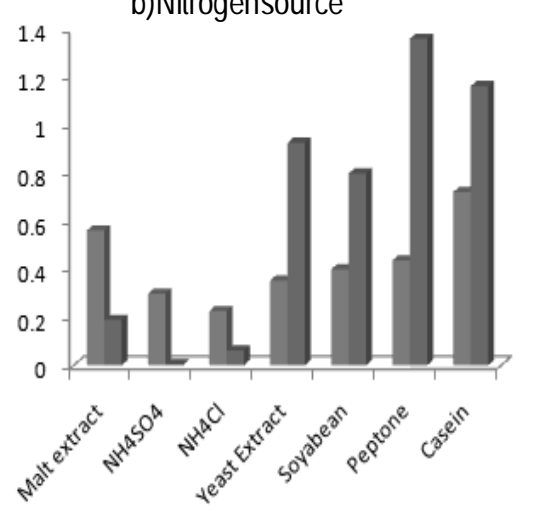

Fig. 2-Effect of Nutritional parameters

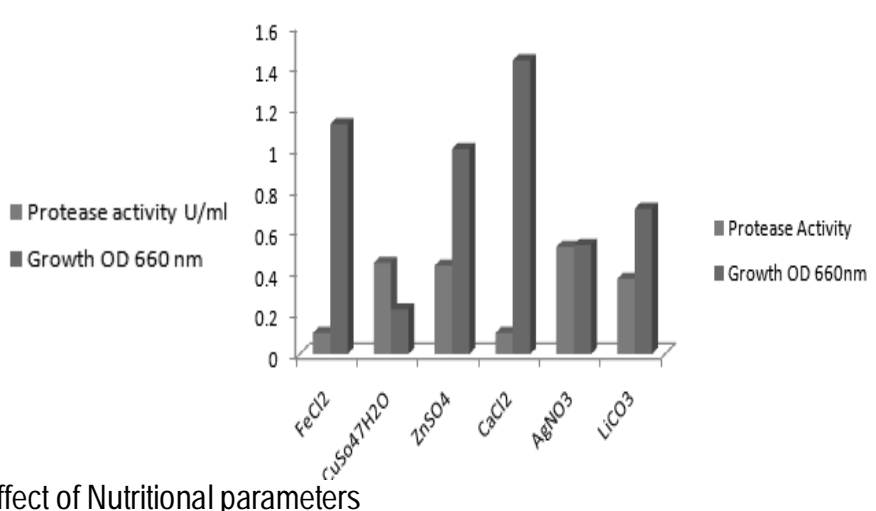

a) Temperature

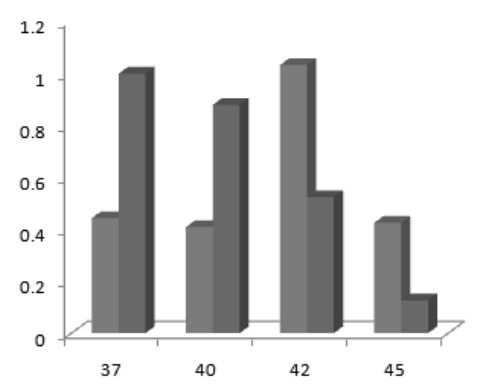

c) Growth Curve : OD vs Time

Growth OD $660 \mathrm{~nm}$

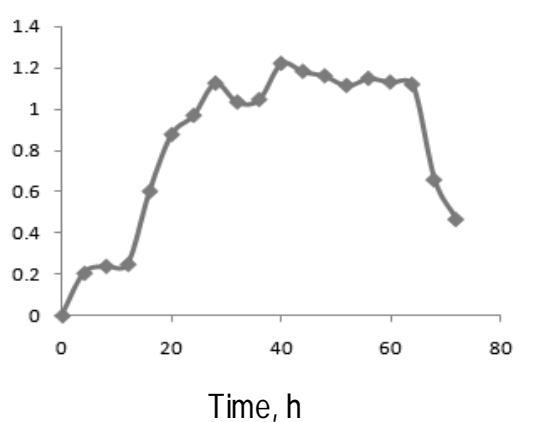

b) $\mathrm{pH}$

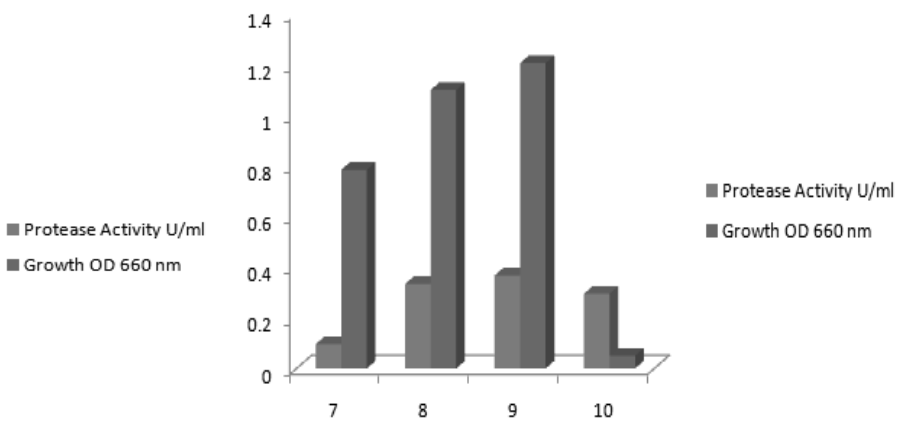

Activity vs Time

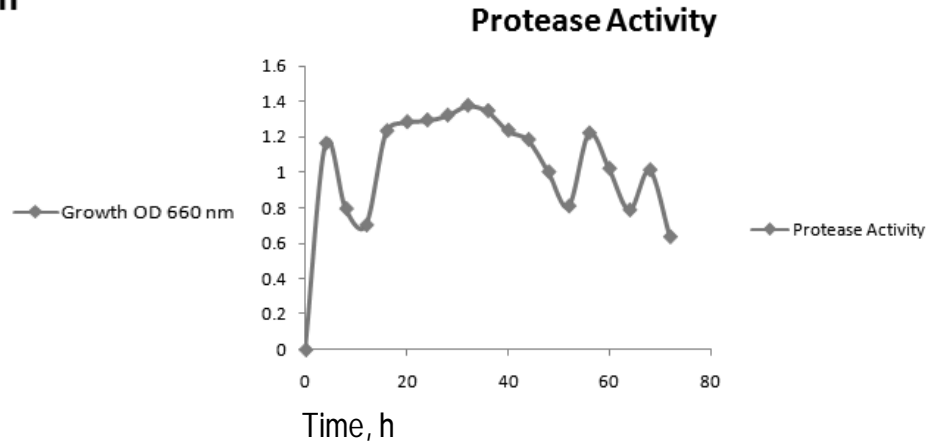

Fig. 3-Effect of Nutritional parameters 